\title{
Overview of fruit flies important for fruit production on the Montenegro seacoast
}

\author{
Sanja Radonjić (1), Snježana Hrnčić ${ }^{(1)}$, Tatjana Perović (2) \\ (1) University of Montenegro, Biotechnical Faculty, Department for Plant Protection, Mihaila Lalića 1, 81000 Podgorica, \\ Montenegro.E-mail: sanjar@ucg.ac.me \\ (2) University of Montenegro, Biotechnical Faculty, Department for Subtropical Cultures, Bjeliši bb, 85000 Bar, Montenegro
}

Received 2 May 2018, accepted 10 January 2019, available online 7 February 2019.

This article is distributed under the terms and conditions of the CC-BY License (http://creativecommons.org/licenses/by/4.0)

Description of the subject. Fruit flies are a large group of pests belonging to the order Diptera. The family Tephritidae is one of two fly families referred to as "fruit flies". Tephritidae (true fruit flies) represent one of the largest families of flies and are part of a group of the most destructive agricultural pests in the world, attacking a wide range of fruits and fleshy vegetables. The other fruit fly family is the Drosophilidae, often called "vinegar flies". There are also fly species from other Diptera families that attack the fruits of agricultural crops.

Objectives. Due to its favorable geographic position and Mediterranean climate, the Montenegro seacoast is suited to fruit and vegetable production. The aim of this study was to make an inventory of the fruit fly species affecting fruit crops on the Montenegro seacoast.

Method. The study area was $300 \mathrm{~km}$ along the Montenegro coast. Different types of traps (lure attractants, pheromone, and yellow sticky traps) were used for the monitoring, detection and recording of the spread of fruit flies in the area.

Results. From an economic point of view, the most important species of fruit flies recorded were the Bactrocera oleae Gmel. and Ceratitis capitata Wiedem. Rhagoletis cerasi L. and Carpomya vesuviana Costa were also found to be present. Although several specimens of Rhagoletis cingulata Loew were detected in 2013-2014, this species has not, to date, been considered as established in the area of study. After the first detection of Drosophila suzukii Matsumura in 2013, this fruit fly was found to spread rapidly, and its presence is now observed along the whole Montenegro seacoast. One of the fruit fly species recorded, Silba adipata McAlpine, is considered to be one of the most destructive pests for fig production in Montenegro.

Conclusions. Of seven species recorded in the study, five belonged to the family Tephritidae, and one each to Drosophilidae and Lonchaeidae.

Keywords. Pest insects, damage, infestation, population dynamics, spatial distribution.

Tour d'horizon des mouches des fruits impliquées dans la production fruitière sur la côte du Monténégro

Description du sujet. Les mouches des fruits représentent un grand groupe de ravageurs qui appartiennent à l'ordre des Diptères. La famille des Tephritidae (les vraies mouches des fruits) est l'une des deux familles de mouches appelées mouches des fruits. Elle appartient à l'une des plus importantes familles et au groupe de ravageurs agricoles les plus destructeurs au monde qui s'attaquent à un large éventail de fruits et de légumes charnus. La seconde famille est celle des Drosophilidae, aussi appelée « mouches du vinaigre ». Il existe d'autres espèces de mouches appartenant à d'autres familles de Diptères qui attaquent les fruits des cultures agricoles.

Objectifs. Grâce à la position géographique favorable et au climat méditerranéen, la côte du Monténégro est propice à la production de fruits et légumes. L'objectif de ce travail est l'inventaire des espèces de mouches des fruits affectant les cultures fruitières des côtes du Monténégro.

Méthode. La zone d'étude est de $300 \mathrm{~km}$, le long de la côte du Monténégro. Différents types de pièges (attractifs, phéromones, pièges collants jaunes) ont été utilisés pour la surveillance, la détection et la distribution des mouches des fruits.

Résultats. Du point de vue économique, les plus importantes espèces sont Bactrocera oleae Gmel. et Ceratitis capitata Wiedem. Les espèces Rhagoletis cerasi L. et Carpomya vesuviana Costa sont présentes aussi. Bien que plusieurs spécimens de Rhagoletis cingulata Loew aient été détectés en 2013-2014, cette espèce n'est pas considérée comme établie jusqu'à présent. Après la première détection de Drosophila suzukii Matsumura en 2013, les ravageurs se sont rapidement propagés et sont maintenant présents le long de toute la côte du Monténégro. Silba adipata McAlpine est considérée comme l'un des ravageurs les plus destructeurs de la production de figues au Monténégro. 
Conclusions. Sur sept espèces recensées, cinq appartiennent à la famille des Tephritidae, une à la famille des Drosophilidae et une à la famille des Lonchaeidae.

Mots-clés. Insecte nuisible, dégâts, infestation, dynamique des populations, distribution spatiale.

\section{INTRODUCTION}

The insect order Diptera is one of the most speciesrich, anatomically varied, and ecologically innovative groups of organisms, making up 10-15\% of known animal species. An estimated 150,000 species of Diptera have been described (Groombridge, 1992 ${ }^{1}$; Thompson, $2005^{2}$ ) although the actual total number of extant fly species is many times that number (Yeates et al., 2007). The family Tephritidae, true fruit flies, includes more than 4,000 species, arranged in 500 genera, and it is amongst the largest families of Diptera. The larvae of most of the tephritid species develop in the seedbearing organs of plants, and about $35 \%$ of the species attack soft fruits, including many commercial fruits. Besides attacking soft fruits, the larvae of about $40 \%$ of tephritid species develop in the flowers of Asteraceae and most of the remaining species are associated with the flowers of other families (White \& ElsonHarris, 1992). Tephritid fruit flies cause devastating direct losses to many fresh fruits and vegetables, and there are about 250 species of Tephritidae that have been known to attack fruits that are either grown commercially, or harvested from the wild. Some species have become pests in regions far removed from their native range. Few insect species have a greater impact on international marketing and world trade in agricultural products than tephritid fruit flies. With expanding international trade, fruit flies, as major quarantine pests of fruits and vegetables, have taken on added importance, triggering the implementation of area-wide national or regional control programs. In addition, quarantine restrictions have to be imposed to limit further spread of fruit fly pests (White \& ElsonHarris, 1992; FAO/IAEA, 2003). Although geneticists and some entomologists use "fruit flies" as the term for the dipteran family Drosophilidae, the term is primarily applied to tephritids. The family Drosophilidae is a diverse, cosmopolitan family of flies that includes over 3,000 described species, distributed all over the world (Wheeler, 1986³). The family Drosophilidae are

\footnotetext{
${ }^{1}$ Groombridge B., ed., 1992. Global biodiversity: status of the Earth's living resources. London: Chapman and Hall, cited in Yeates et al. (2007).

${ }^{2}$ Thompson F.C., ed., 2005. Biosystematic database of world diptera. Version 7.5, cited in Yeates et al. (2007).

${ }^{3}$ Wheeler M.R., 1986. Additions to the catalog of the world's Drosophilidae. In: Ashburner M., Thompson J.N. \& Carson H.L., eds. The genetics and biology of Drosophila, Vol. 3. London: Academic Press, 1-105, cited in Yeates et al., 2007, cited in Remsen \& O'Grady (2002).
}

considered to be nuisance flies rather than pests, since most of the family's species breed in rotting material. Some members of the genus Drosophila are parasitic and some drosophilid larvae are predatory, feeding upon bee larvae, scale insects, and even frog and spider embryos (Ashburner, 1989; Carson, 19744). Of the 1,500 species of Drosophila (Markow \& O'Grady, $2006^{5}$ ), commonly known as vinegar flies, most are not defined as pests because they infest overripe, fallen, rotting fruit (EPPO/OEPP, 2010). The spotted wing drosophila (Drosophila suzukii Matsumura) is one of only two species known to oviposit in healthy fruits as opposed to fruit that is damaged or overripe (Sasaki \& Sato, 19956; Sasaki \& Sato, $1996^{7}$ ). There are also fly species from other Diptera families that attack the fruits of agricultural crops. The Lonchaeidae, a small family with 500 species in nine genera is known worldwide and is found in a wide range of habitats. In Europe, there are over 100 described species in eight genera. Although primarily associated with living or decaying plant tissue, including herbs and trees in Europe, many species live under the bark of dead and dying trees, or in decomposed wood. The larvae of Silba and Lamprolonchacea usually develop in fruits and vegetables, and sometimes appear as a pest of commercial crops (Ferrar, 1987 $)$.

Fruit flies cause direct damage by puncturing the fruit skin to lay eggs underneath it. Hatched larvae cause the destruction of host fruits, converting the flesh into an inedible mass (qualitative damage). Infested fruits often drop prematurely. This results in a reduction in fruit production (quantitative damage), increasing insecticide use and production costs, and causing problems with international trade.

\footnotetext{
${ }^{4}$ Carson H.L., 1974. Three flies and three islands: parallel evolution in Drosophila. Proc. Natl. Acad. Sci. U.S.A., 71 3517-3521, cited in Remsen \& O'Grady (2002).

${ }^{5}$ Markow T.A.\& O’Grady P.M., 2006. Drosophila: a guide to species identification and use. London: Academic Press, 13 , cited in Walsh et al. (2011).

${ }^{6}$ Sasaki M. \& Sato R., 1995. Bionomics of the cherry drosophila, Drosophila suzukii Matsumura (Diptera: Drosophilidae) in Fukushima prefecture (Japan). Annu. Rep. Soc. Plant Prot. North Japan, 46, 164-172, cited in Walsh et al. (2011).

${ }^{7}$ Sasaki M. \& Sato R., 1996. Bionomics of Drosophila pulchrella Tan, Hus et Sheng (Diptera: Drosophilidae) in Fukushima prefecture (Japan). Tohoku Agric. Res., 49, 161162 , cited in Walsh et al. (2011).

${ }^{8}$ Ferrar P., 1987. A guide to the breeding habits and immature stages of Diptera Cyclorrhapha. In: Lyneborg L., ed. Entomonograph. Vol. 8, part 1: text. Leiden, The Netherlands: Brill, cited in MacGowan \& Freidberg, 2008
} 
In Montenegro, plant production is generally characterized by a large number of small agricultural holdings, all of which grow different crops. Favorable natural conditions enable the production of fruits (citrus and continental), viticulture, olives, crops, and vegetables (Anonymous, 2015). According to the Statistical Yearbook of Montenegro (Anonymous, 2017), total production in tonnes of some important fruits and olives in 2016 was as follows: olives 766.50, mandarins 4,485, peaches 884.60, apples 7,968.10, plums 13,127.60, pears 2,612.70, and grapes 30,153. The most economically important tree fruit crops from the Montenegro seacoast are citrus and olive. Although these fruits are primarily for the domestic market, there is some exportation of mandarins and olive oil.

According to Anonymous (2015), citrus production is the highest (24.4\%), with satsuma mandarins (Citrus unshiu Marc.) being the crop most predominantly grown. Olive trees are the oldest subtropical crop on the Montenegro seacoast, with a cultivation tradition of over 2,000 years. The number of olive trees is 489,520 , with a constant growth in numbers over the last ten years. The most predominant domestic cultivar is 'Žutica' (65\%), followed by other domestic and introduced cultivars (Anonymous, 2017). Other fruit species, such as figs, persimmons, pomegranate, jujube, actinidia, apples, stone fruits, and grapes are of lesser importance. According to Hrnčić (2000, 2001), damage caused by Ceratitis capitata resulted in a premature fruit drop rate, in 2000 and 2001, of up to $80 \%$ in some mandarin plantations on the Montenegro seacoast. Depending on the year, the olive fly may reduce crop production by up to $40-50 \%$ (Mijušković \& Mirčetić, 1955).

An overview of tephritid fruit flies and other dipteran flies recorded as a pest of fruit species on the Montenegro seacoast is presented in this paper.

\section{MATERIALS AND METHODS}

\subsection{Study area}

The study area covered $300 \mathrm{~km}$ along the Montenegro seacoast, which borders the Adriatic Sea, between $41^{\circ} 52^{\prime}$ and $42^{\circ} 29^{\prime}$ north latitude and $18^{\circ} 26^{\prime}$ 'and $20^{\circ} 22^{\prime}$ east longitude, with an elevation above sea level of up to $140 \mathrm{~m}$. The climate of this area is characterized by long, warm summers and mild winters, with large amounts of precipitation (ZHMS, 2018), and is classified as Mediterranean (UNDP, 2018). With the exception of the areas of Ulcinj and Bar, where most commercial groves of citrus and olives are situated, the rest of the seacoast is characterized by small, mixed family orchards (mostly growing mandarins, olives, figs, persimmons, jujube, peaches, apples, and pomegranates). These fruits are also grown in the backyards of private houses. In both these small growing areas control methods against pests are rarely used. For the purposes of the present study, visual inspections were made by the authors, in order to monitor and detect the presence of fruit fly species in the area. These inspections were authorized by the Phytosanitary Directorate of Montenegro, Ministry of Agriculture and Rural Development (Figure 1, Table 1).

\subsection{Fruit fly monitoring}

Two species, the olive fruit fly (Bactrocera oleae Gmel.) and the Mediterranean fruit fly (Ceratitis capitata Wiedem.) have been under continuous monitoring for many years, as they were already established in the area of study, while other fruit fly species were found in situ during regular field inspections. Three different types of traps (lure attractants, pheromone, and yellow sticky traps) were used for the monitoring and detection of the presence and spread of pests.

Throughout the years of monitoring, the following traps and attractants were used for $C$. capitata (in chronological order): McPhail traps with angelica seed oil (2002-2003); Jackson traps with para-pheromone

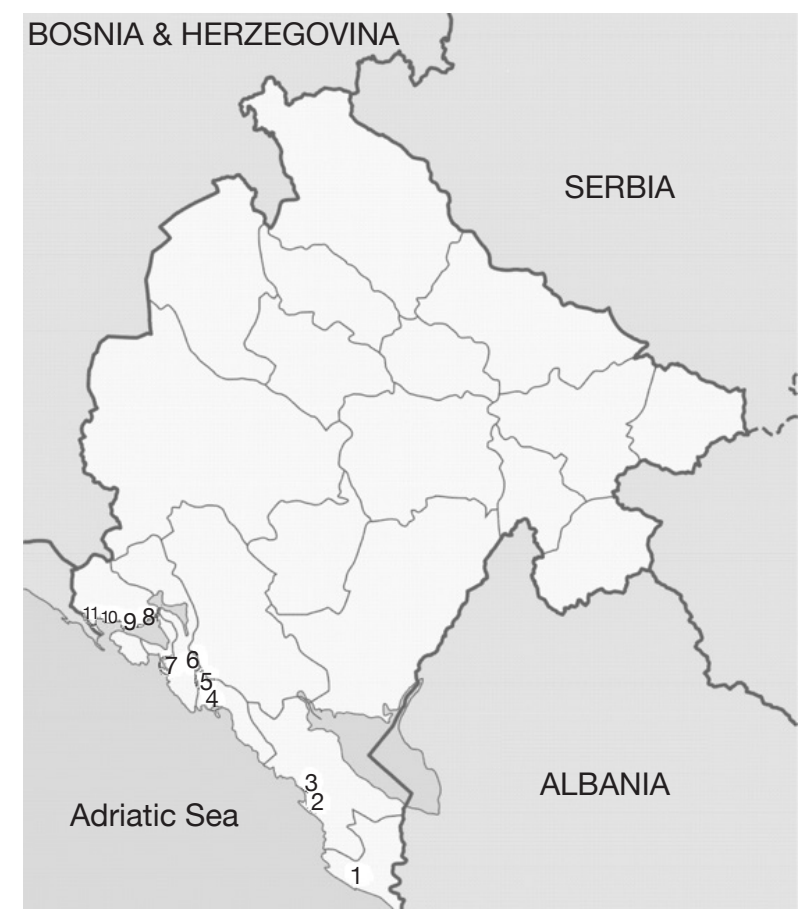

Figure 1. Study sites for the monitoring and detection of the presence of fruit flies - Sites d'étude pour la surveillance, la détection et la présence de mouches des fruits.

1: Ulcinj; 2: Bar; 3: Šušanj; 4: Budva; 5: Lastva Grbaljska; 6: Radanovići; 7: Bigova; 8: Baošići; 9: Đenovići; 10: Kumbor; 11: Herceg Novi. 
Table 1. Latitudes, longitudes and elevations above sea level for the study area - Latitudes, longitudes et élévations audessus du niveau de la mer pour la zone d'étude.

\begin{tabular}{llll}
\hline Area/Locality & Latitude (North) & Longitude (East) & Elevation above sea level (m) \\
\hline Area of Ulcinj & $41^{\circ} 53^{\prime} 15^{\prime \prime}-41^{\circ} 56^{\prime} 28^{\prime \prime}$ & $19^{\circ} 21^{\prime} 23^{\prime \prime}-19^{\circ} 10^{\prime} 56^{\prime \prime}$ & $5-120$ \\
\hline Area of Bar & $42^{\circ} 02^{\prime} 55^{\prime \prime}-42^{\circ} 5^{\prime} 15^{\prime \prime}$ & $19^{\circ} 6^{\prime} 10^{\prime \prime}-19^{\circ} 08^{\prime} 35^{\prime \prime}$ & $10-140$ \\
\hline Šušanj & $42^{\circ} 06^{\prime} 44^{\prime \prime}$ & $19^{\circ} 06^{\prime} 01^{\prime \prime}$ & 50 \\
\hline Budva & $42^{\circ} 17^{\prime} 12^{\prime \prime}$ & $18^{\circ} 51^{\prime} 10^{\prime \prime}$ & 10 \\
\hline Lastva Grbaljska & $42^{\circ} 18^{\prime} 25^{\prime \prime}$ & $18^{\circ} 48^{\prime} 11^{\prime \prime}$ & 15 \\
\hline Radanovići & $42^{\circ} 21^{\prime} 59^{\prime \prime}$ & $18^{\circ} 45^{\prime} 18^{\prime \prime}$ & 85 \\
\hline Bigova & $42^{\circ} 22^{\prime} 40^{\prime \prime}$ & $18^{\circ} 44^{\prime} 32^{\prime \prime}$ & 37 \\
Baošići & $42^{\circ} 26^{\prime} 38^{\prime \prime}$ & $18^{\circ} 37^{\prime} 53^{\prime \prime}$ & 3 \\
\hline Đenovići & $42^{\circ} 26^{\prime} 14^{\prime \prime}$ & $18^{\circ} 36^{\prime} 30^{\prime \prime}$ & 26 \\
\hline Kumbor & $42^{\circ} 26^{\prime} 19^{\prime \prime}$ & $18^{\circ} 35^{\prime} 53^{\prime \prime}$ & 10 \\
\hline Herceg Novi & $42^{\circ} 27^{\prime} 01^{\prime \prime}$ & $18^{\circ} 31^{\prime} 25^{\prime \prime}$ & 38 \\
\hline
\end{tabular}

Trimedlure (TML) - a male-specific attractant (20042006); McPhail traps with a mixture of hydrolyzed protein (Buminal) + diammonium hydrogen phosphate, $4: 1$ (2006-2008); Tephri traps baited with three-component female-biased dry food attractant (ammonium acetate, trimethylamine, and putrescine) from Suterra (Bend, OR, USA) and insecticide dichlorvos (DDVP stripes) from AgriSense-BSC Ltd. (Pontypridd, South Wales, UK) (used continuously since 2008); and Jackson traps (Scentry Biologicals INC., Billings, MO, USA) with Trimedlure (used continuously since 2013).

Traps were set up and were regularly checked from mid-May to the end of December in commercial citrus orchards, as well as in small mixed orchards and backyards, and were checked at two-week intervals along the whole coastal area. In some cases, several traps remained in place throughout the winter in backyards or small mixed orchards in urban areas.

Throughout the years of monitoring, the following traps and attractants were used for $B$. oleae: McPhail traps baited with ammonia salts (diammonium hydrogen phosphate or ammonium sulphate, 2-4\%) continuously, and yellow sticky traps since 2004. Traps were set up in mid-June and checked at weekly intervals until the end of October/beginning of November (olive harvesting season). Since 1998, traps had also been set up and checked continuously in commercial olive orchards in two main production areas (Ulcinj and Bar), as well as sporadically along the whole seacoast.

Yellow sticky traps were used for the ber fruit fly (Carpomya vesuviana Costa) in backyards and were checked at 7-15 day intervals from mid-June to the end October in 2012 in the localities of Budva, Bar, and Ulcinj.

McPhail traps baited with ammonium acetate, used for the eastern cherry fruit fly (Rhagoletis cingulata
Loew), were set up in mixed orchards, during the period 2013-2016 in the localities of Lastva Grbaljska, Bigova, Baošići, Bar, and Ulcinj.

Tephri traps baited with the three-component synthetic dry food attractant and insecticide DDVP were used for the monitoring of Drosophila suzukii from 2014. Traps were set up along the whole seacoast in mixed orchards from mid-May and were moved into the orchard following the pheno-phase of development of available host fruits.

No traps were used for the European cherry fruit fly (Rhagoletis cerasi L.) or the black fig fly (Silba adipata McAlpine); only fruit sampling was used in these cases.

\subsection{Collection of fruits and rearing of fruit flies}

Visual inspections of selected fruits and sampling of suspicious fruits were carried out from the beginning of the ripening phase. Sampled fruits were examined in the Entomology laboratory of the Biotechnical Faculty (Podgorica, Montenegro). Where larval/pupal presence was detected, the flies were reared in cages and plastic boxes at room temperature until adult emergence. In cases where B. oleae was identified, the presence of development stages (eggs, larvae, pupae, and empty galleries) in olive fruits was checked at weekly sampling intervals, in order to calculate the percentage of active infestation.

\subsection{Fruit fly identification}

Newly recorded species were identified via the morphological features of adults and larvae, with reference to the following morphological keys: Bodenheimer (1951), White \& Elson-Harris (1992), 
and EPPO/OEPP (2013). In most cases, photographs of living specimens and/or injury symptoms were taken.

\section{RESULTS AND DISCUSSION}

An inventory of fruit fly species attacking fruit crops on the Montenegro seacoast is presented in the following order.

\subsection{Family Tephritidae}

Bactrocera oleae Gmel. - The olive fruit fly. Bactrocera oleae is the most important olive pest in Montenegro, having been established there for decades. Monitoring showed the presence of this fruit fly along the whole Montenegro coastal area and identified its flight activity from the beginning of July until the end of November. The population dynamics of the olive fruit fly in the main production areas were found to be characterized by fluctuations, which varied according to the year, and to the prevailing weather conditions during the summer months, particularly the temperature and relative humidity. Generally, the population density of this pest was found to be low until the end of August. It rapidly increased during September and then gradually decreased from mid-October onwards. Fly captures were registered during December and January on yellow sticky traps that remained throughout the winter of 2005 in one commercial olive orchard (Perović et al., 2009). In cases where high temperatures in July and August were followed by low relative humidity, low captures of adults and low fruit infestations were noted, even in cases without control measures (Hrnčić, 2002; Hrnčić, 2017).

Inspections of sampled fruits showed that high temperatures at the beginning of July were limiting for the development of eggs and the first instar larvae (L1). Infestations increased from the end of July to the end of August, reaching 5-20\%. In September and October, the infestation multiplied and, by the end of October, levels were usually found to be over $75 \%$, although in some years, they reached 90\% (Hrnčić, 2009, 2014, 2016) (Figure 2). Regarding the infestation structure, eggs and L1 were dominant until the middle of September. From that period until the middle of October, the numbers of eggs, larvae, and pupae were equal in infested fruits, while pupae, empty cocoons, and empty galleries prevailed until the harvest (Perović \& Hrnčić, 2013).

During years that are particularly favorable to its development, the olive fly is known to be able to cause damage and to reduce crop production by up to 40-50\% (Mijušković \& Mirčetić, 1955). The olive fruit

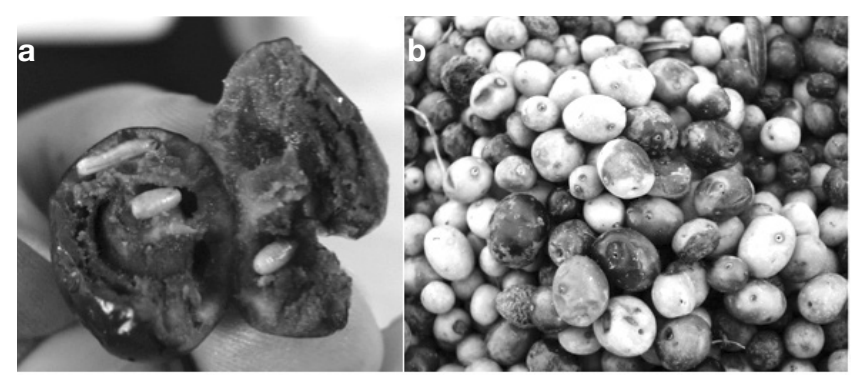

Figure 2. Bactrocera oleae.

a. larvae and pupae in olive fruit - larves et nymphes dans les olives; $\mathbf{b}$. damaged olive fruits - olives infestées.

fly is the most serious pest of olives in Mediterranean countries. Economic losses due to this pest have been estimated to reach up to $15 \%$ of the olive crop, in spite of the fact that pesticide treatments are applied every year to control the fly population (Mazomenos et al., 2002). The olive fruit fly infests the olive fruit and causes damage of a quantitative and qualitative nature. Potential crop losses that can be caused by this pest during periods and in locations with conditions favoring high population densities, and where no control measures are taken, are quoted by various authors to be as high as $80 \%$ of production, with an average of 40-50\%. However, average crop loss levels, which usually occur with the control measures applied currently, vary between $5-15 \%$, depending on the country (Haniotakis, 2005).

Ceratitis capitata Wiedem. - The Mediterranean fruit fly. Ceratitis capitata has been considered as an established pest in Montenegro since the early 2000s (Figure 3). Although this pest has been present in the Mediterranean region for more than a century, there was previously no permanent monitoring in Montenegro. However, some records do exist, and sporadic detections of very low populations have previously been noted (Mijušković, 1959; Velimirović, 1988, 1989, 1990). After serious damage was caused in mandarin commercial citrus orchards in the areas of Bar and Ulcinj in 2000, as well as in some localities

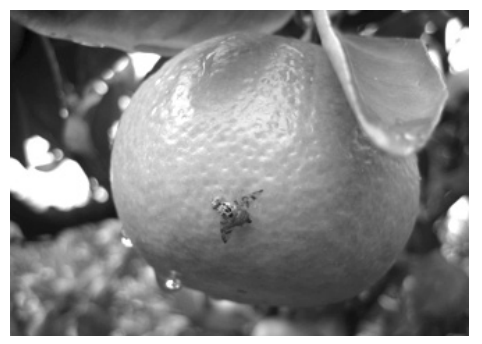

Figure 3. Ceratitis capitata: adult on a mandarin fruit adulte sur mandarinier. 
surrounding the city of Budva and in the area of Boka Kotor Bay in 2001 (Hrnčić, 2000, 2001), continuous monitoring started in 2002. Results of monitoring have shown the presence of $C$. capitata along the whole coastal area (Radonjić, 2006; Radonjić, 2008; Radonjić et al., 2013), and a distinct seasonal occurrence of population fluctuation. In general, captures of flies have been recorded from the end of June until the end of December. Population density has been found to be very low in July and August, increasing slowly from the end of August and through the first half of September, and then peaking from mid-September through to the end of October. Adult activity has been found to end in December (Radonjić et al., 2013). These seasonal variations in population dynamics are similar to those recorded in other locations that are close to the northern limits of $C$. capitata distribution in Europe (Papadopoulos et al., 2001; Bjeliš et al., 2007; Escudero-Colomar et al., 2008). In the present study, generally no adult activity was found in the winter. However, during the relatively warm winter of 2013-2014, several flies were captured at the beginning of February in Jackson traps with TML, which had remained in some backyards in the Kumbor locality. These findings, taken together with the evidence of low captures in December and January in several localities, could lead to the assumption of possible adult activity during mild winters (Radonjić, 2014). The population dynamics of the Mediterranean fruit fly have been found to be closely linked with the availability and abundance of the host fruits. Infested plants that have been detected since 2002 include: mandarins (Citrus reticulata Blanco), oranges (Citrus sinensis [L.] Osbeck), lemon - cultivar Lunario (Citrus limon [L.] Osbeck), grapefruit (Citrus paradise Macf.), figs (Ficus carica L.), persimmon (Diospyros kaki L.), jujube (Ziziphus jujube Mill.), apples (Malus domestica Borkh.) (Radonjić, 2008; Radonjić \& Hrnčić, 2011), and peaches (Prunus persicae [L.] Batsch) (Radonjić, 2012). Figs are the first available hosts (July-August) and were found to contribute to the $C$. capitata population increase during the summer months, which later caused economic damage to mandarins, the most economically important host in Montenegro (midSeptember to November) (Figure 4). As the presence of suitable host fruits increased during September and October (different mandarin cultivars, persimmons), this was found to result in population build-up (Table 2) (Radonjić et al., 2013).

Ceratitis capitata is a highly invasive, the most widespread and probably the most serious pest species in the entire Tephritidae family. According to Liquido et al. (1998), this species is highly polyphagous, and is known to infest 374 types of fruit. It has a high dispersive ability, a very large host range and a tolerance of both natural and cultivated habitats over a comparatively wide temperature range. It has a high economic impact, affecting production, control costs and market access. Its pattern of host relationships from region to region appears to relate largely to what fruits are available. The transport of infested fruits is the major means of movement and dispersal of this fruit fly to previously uninfested areas (White \& Elson-Harris, 1992; Liquido et al., 1998; CABI, 2014).

Carpomya vesuviana Costa-The ber fruit fly. The ber fruit fly is a monophagous species, attacking exclusively jujube, both wild and cultivated. In 2011, the dropping of many jujube fruits containing dipteran larvae was noted in the areas of Bar and Ulcinj. As the presence of C. vesuviana had already been confirmed on jujube in neighboring Croatia (Bjeliš, 2009), yellow sticky traps

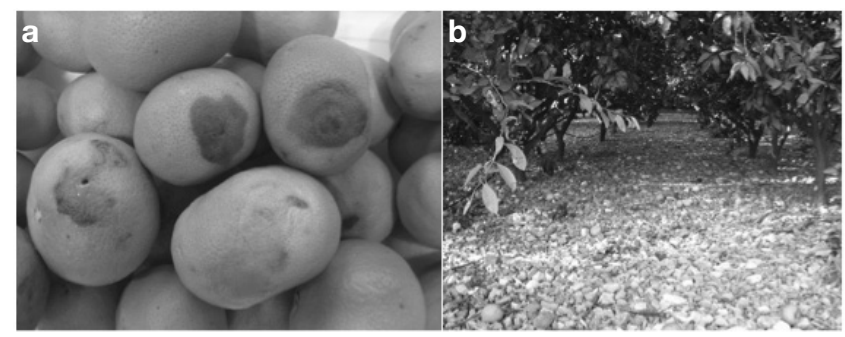

Figure 4. Ceratitis capitata damage - Dégâts causés par Ceratitis capitata.

a. infested mandarin fruits - mandarines infestées; b. fallen mandarin fruits - mandarines tombées.

Table 2. Ripening period of the most important Ceratitis capitata host plants - Période de mûrissement des plantes hôtes les plus importantes de Ceratitis capitata.

\begin{tabular}{|c|c|c|c|c|c|c|c|}
\hline Host plants & June & July & August & September & October & November & December \\
\hline Fig & $\mathrm{x}$ & $\mathrm{X}$ & $\mathrm{x}$ & & & & \\
\hline Mandarin ('Wakyama', 'Chahara') & & & & $\mathrm{x}$ & & & \\
\hline Mandarin ('Kawano Wase') & & & & & $\mathrm{x}$ & & \\
\hline Persimmon & & & & & $\mathrm{x}$ & & \\
\hline Mandarin ('Owari’) & & & & & $\mathrm{x}$ & $\mathrm{x}$ & \\
\hline Orange ('Washington Navel') & & & & & & $\mathrm{x}$ & $\mathrm{x}$ \\
\hline
\end{tabular}


were set up in mid-June 2012 in Montenegro, in order to determine the possible presence of the genus Carpomya there. The first captured flies were recorded in late June in Bar and in July in Ulcinj and Budva. The presence of $C$. vesuviana was confirmed in the laboratory via the morphological features of the captured flies and emerged adults from infested fruits (Figure 5). This was the first official record of the presence of the ber fruit fly in Montenegro. The maximum number of captured flies was registered in September in all the localities under investigation. Adult flies were found to be active until the end of October. The level of fruit infestation was found to be related to the number of captured flies, which varied between the inspected localities. The highest infestation rate of up to $76 \%$ was found in Ulcinj, while in Bar and Budva, levels did not exceed 20\% (Perović \& Hrnčić, 2012). Damage caused by $C$. vesuviana was of local importance, due to the fact that jujube are grown as individual trees along the seacoast (Figure 6).

Carpomya vesuviana is a widespread pest of the jujube tree in India, Pakistan and the Middle East and it can cause significant damage by reducing the fruit yield by up to $80 \%$, in some cases by even $100 \%$. Infested fruits have a bitter taste and are not suitable for use (Vadivelu, 2014).

Rhagoletis cingulata Loew - The eastern cherry fruit fly. As part of the present study, $R$. cingulata was detected for the first time, in August 2013, in a cherry orchard in Lastva Grbaljska (Figure 7). At that

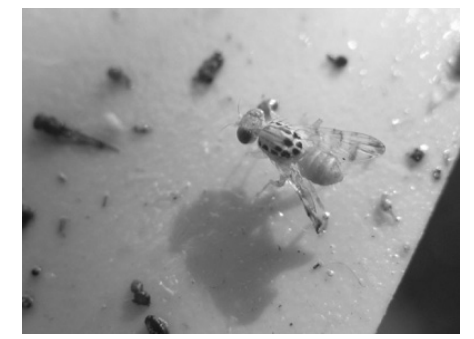

Figure 5. Carpomya vesuviana: adult on a yellow sticky trap - adulte sur un piège collant jaune.

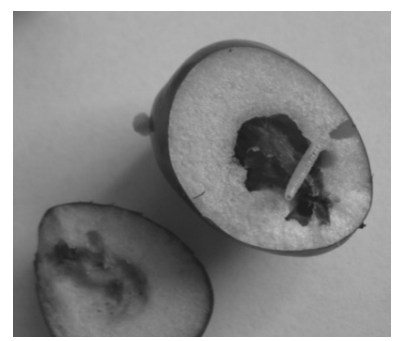

Figure 6. Carpomya vesuviana: infested jujube fruit - fruit de jujube infesté.

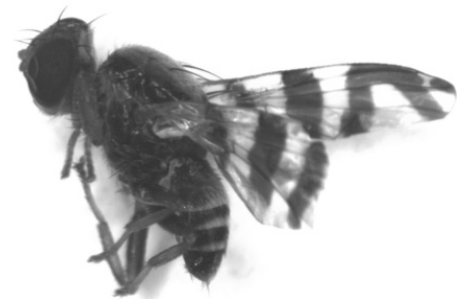

Figure 7. Rhagoletis cingulata: adult - adulte.

time, only one specimen (male) of this fruit fly was captured (Radonjić, 2013). In the following two years, McPhail traps were set up in four additional localities: Ulcinj, Bar, Baošići, and Bigova. Monitoring from 2014 onwards showed either no repeated records in this locality or detection in other localities, except in 2014 when several flies were captured again in Lastva Grbaljska in July and August. To date, this pest is considered not to be established in Montenegro.

Rhagoletis cingulata is an eastern North American species. It is an important quarantine pest for temperate regions and is listed on the EPPO A2 list as a severe pest of cherries. Adult flight and the transport of infected fruits are the major means of movement and dispersal to previously uninfected areas. This species is known to be present in Europe, with a few occurrences being recorded in Austria, Belgium, the Czech Republic, Hungary, and Slovenia, and with restricted distribution reported in Germany, The Netherlands, and Switzerland; the species is also present in Croatia (CABI, 2008).

Rhagoletis cerasi L. - The European cherry fruit fly. Although being a highly destructive pest of cherries (Prunus spp.), present in most European countries, $R$. cerasi is not included in the Montenegro monitoring program. Its main commercial hosts, sweet cherry (Prunus avium L.) and bitter cherry (Prunus cerasus L.), are of minor economic importance on the Montenegro seacoast, with these fruits being present sporadically in backyards or as a part of small mixed orchards. The presence of $R$. cerasi has been recorded every year in localities on the seacoast (Bar, Lastva Grbaljska, Baošići, and Bigova), starting from the end of May. Captures were recorded in yellow sticky traps or in McPhail traps baited with ammonium acetate, used for the monitoring of other tephritids (Radonjić \& Hrnčić, unpublished data).

\subsection{Family Drosophilidae}

Drosophila suzukii Matsumura - The spotted wing drosophila. Drosophila suzukii was recorded for the first time in October 2013 in citrus-producing orchards in the localities of Đenovići, Kumbor, and Baošići. A 
quick check of the rest of the seacoast confirmed the presence of this pest in all the inspected localities. The flies were found unexpectedly in Tephri traps baited with the three-component synthetic dry food attractant, used regularly, in the present study, for the monitoring of $C$. capitata (Figure 8). Both sexes were captured in traps (Radonjić \& Hrnčić, 2015). In 2014 and 2015, the first captures were recorded from the end of August, gradually increasing in September, but, in particular, from the beginning of October onwards (Radonjić, 2014, 2015). In 2016, the presence of this pest was confirmed in all the inspected localities along the seacoast (Herceg Novi, Baošići, Đenovići, Kumbor, Lastva Grbaljska, Bar, and Ulcinj). The first captures were recorded from mid-September, and continued during October and November. In the Baošići and Herceg Novi areas, the maximum number of captured flies was recorded during the second half of October, while in Ulcinj, Bar, and Lastva Grbaljska, the maximum number was found in early November (Radonjić, 2016). The same capture pattern was recorded in 2017. In that year, for the first time, the fruits of host plants were sampled after their ripening period. Infested sweet cherry fruits were found in mid-June in Bigova; blackberries were found in July and August and figs in September, in Bigova and Bar (Radonjić, 2017). The presence and establishment of $D$. suzukii along the seacoast, as well as confirmed infestations of several host species, represents a serious threat for fruit growing in this area. Moreover, the fact that these hosts are of minor economic importance, and that growers traditionally do not apply control measures, could contribute to the maintenance and increase of the population of this pest from year to year.

Drosophila suzukii is a highly polyphagous species, which infests a wide range of fruit crops, as well as an increasing number of wild fruits. It is an endemic species to South East Asia that has recently invaded western countries. Its pattern of egg laying and feeding on unwounded ripening fruit of many plant species, particularly berries and stone fruits, its high dispersal
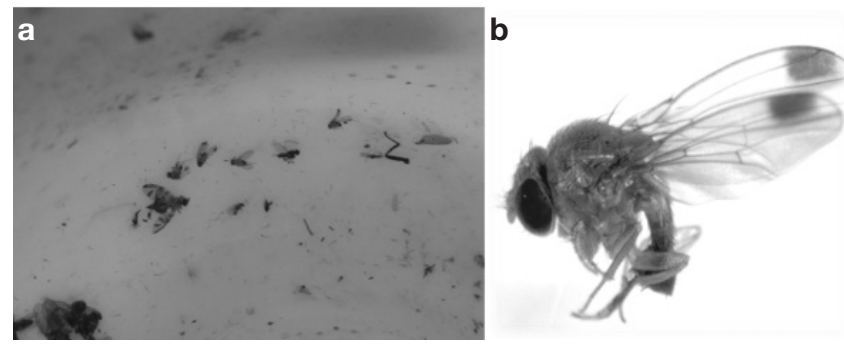

Figure 8. Drosophila suzukii.

a. adults captured in a Tephri trap - adultes capturés dans le piège de Tephri; $\mathbf{b}$. adult male - mâle adulte. potential and its tolerance of a wide range of climatic conditions, make this pest a real threat to the fruit industry of the countries concerned (Cini et al., 2012; CABI, 2013).

\subsection{Family Lonchaeidae}

Silba adipata McAlpine - The black fig fly. In August 2004, dipteran larvae, smaller and more tender than the larvae of $C$. capitata (previously the only known dipteran fig pest in Montenegro) were found in mature fig fruits (cv. 'Patlidžanka') in Lastva Grbaljska. The presence of $S$. adipata was confirmed via the morphological features of the larvae (posterior spiracles), pupae and emerged adults observed in laboratory from sampled fruits (Figure 9). This was the first official record of this species in Montenegro. The same larvae were found in July and August 2005, in Radanovići and Šušanj, in premature green dropped fig fruits (cv. 'Rezavica' and 'Sušalica') and in August and September in semi-ripened and ripened fruits of cv. 'Patlidžanka' in Lastva Grbaljska. According to Radonjić \& Hrnčić (2009), infestation of unripe figs by the black fig fly was one of the main reasons for the recorded premature fruit drop. Although the fig is not of economic importance in Montenegro, it is widespread along the seacoast, either as individual trees or within small orchards. Direct damage caused by the feeding larvae was found to result in premature fruit drop and the destruction of a large proportion of edible fruits (Figure 10). It reduced the, already small, fig production in the area of study.

Silba adipata is known to be present in Spain, Italy, Greece, Cyprus, the Canary Islands, Syria, Israel, Jordan, Iraq, Egypt, South Africa, and Malta (MacGowan \& Freidberg, 2008; Mifsud et al., 2012). It is exclusively found on Ficus carica, where its larvae feed on the tissue of the syconia, just under the peel, destroying the fruit and causing unripe fruit to fall prematurely (Mifsud et al., 2012).

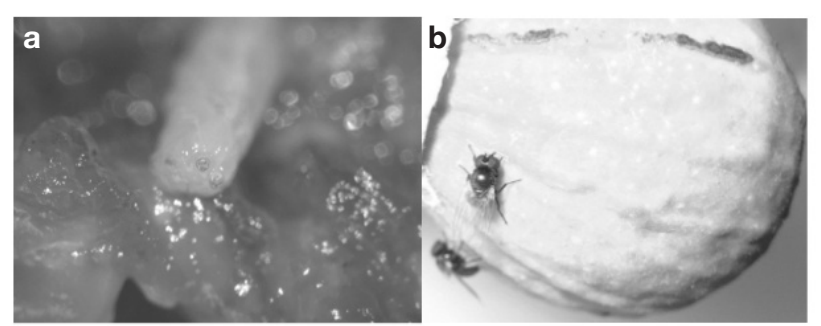

Figure 9. Silba adipata.

a. posterior spiracles of larvae - stigmates postérieurs des larves; b. adults on a fig fruit - adultes sur figue. 


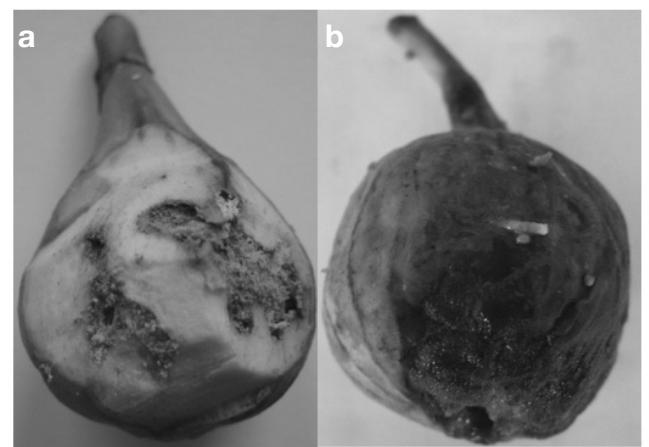

Figure 10. Silba adipata damaged figs - Dégâts de Silba adipata sur des figues.

a. unripe fruit - fruit non mûr; b. mature fruit - fruit mûr.

\section{CONCLUSIONS}

An inventory of fruit fly species was obtained using three different types of traps (lure attractants, pheromone, and yellow sticky traps) for adult detection. Visual inspections and the sampling of suspicious fruits for larval presence were also carried out. This study has summarized data on fruit flies of economic importance along the Montenegro seacoast. Based on our results, we can conclude that the species of fruit fly pests found belonged to the families Tephritidae, Drosophilidae, and Lonchaeidae. Of seven recorded species, only $R$. cingulata is considered not to be established in the study area, to date. From an economic point of view, of the established fruit fly species in the region, the most important are the tephritids, B. oleae and $C$. capitata, because of their negative effects (damage of a quantitative and qualitative nature) on olive and citrus production, representing the most important fruit crops on the Montenegro seacoast. As a newly successfully established species, D. suzukii showed a high rate of spread across the whole seacoast. As a highly polyphagous species, this species can be considered to be of economic concern for a variety of fruit crops growing not only along the seacoast, but also in other parts of Montenegro. The remaining pests recorded (C. vesuviana, $R$. cerasi, and $S$. adipata) are of lesser economic importance, due to their host plants being in the minority there. On the other hand, as these species are monophagous, they can still be considered as harmful to the fruits of their respective host plants.

The results of this study recorded dipteran flies as a pest of various fruit species on the Montenegro seacoast. This is of importance for commercial and small stakeholders in the fruit-producing sector, who rely upon the early warning and early detection of fruit flies, in order to ensure the timely application of control measures.

\section{Acknowledgements}

The authors would like to thank the Directorate for Food Safety, Veterinary and Phytosanitary Affairs, Ministry of Agriculture and Rural Development of Montenegro for their financial support. Also, many thanks go to entomology technician Milorad Raičević for his help in the field and laboratory work, and especially to the fruit producers and growers that allowed us to set up traps in their orchards and to sample fruits during the whole period of this study.

\section{Bibliography}

Anonymous, 2015. Strategy for the development of agriculture and rural areas 2015-2020. Final Report. Podgorica: Government of Montenegro, Ministry of Agriculture and Rural Development.

Anonymous, 2017. Statistical yearbook of Montenegro. Chapter 11, Agriculture. Podgorica: Monstat, 96-112.

Ashburner M., 1989. Drosophila: a laboratory handbook. Cold Spring Harbor, NY, USA: Cold Spring Harbor Laboratory Press.

Bjeliš M., 2009. Voćne muhe - Tephritidae gospodarskog i faunističkog značenja za područje Hrvatske. Zagreb: Institute for Plant Protection in Agriculture and Forestry of the Republic of Croatia.

Bjeliš M. et al., 2007. Spatial distribution and temporal outbreaks of medfly - Ceratitis capitata Wied. (Diptera, Tephritidae) in Republic of Croatia. In: Proceedings of the $8^{\text {th }}$ Slovenian Conference on Plant Protection, 6-7 March 2007, Plant Protection Society of Slovenia, Radenci, Slovenia, 321-325.

Bodenheimer F.S., 1951. Citrus entomology in the Middle East with special references to Egypt, Iran, Irak, Palestine, Syria, Turkey. 's-Gravenhage, The Netherlands: Junk.

CABI, 2008. Rhagoletis cingulata (cherry fruit fly), http: www.cabi.org/isc/datasheet/47051, (April 2018).

CABI, 2013. Drosophila suzukii (spotted wing drosophila), http:www.cabi.org/isc/datasheet/109283, (April 2018).

CABI, 2014. Ceratitis capitata (Mediterranean fruit fly), http:www.cabi.org/isc/ datasheet/12367, (April 2018).

Cini A., Loriatti C. \& Anfora G., 2012. A review of the invasion of Drosophila suzukii in Europe and a draft research agenda for integrated pest management. Bull. Insectology, 65(1), 149-160.

EPPO/OEPP, 2010. Drosophila suzukii (Diptera: Drosophilidae) spotted wing drosophila. A pest from the EPPO alert list, http:www.eppo.int/ QUARANTINE/Alert_List/insects/Drosophila_suzukii_ factsheet_12-2010.pdf, (April 2018).

EPPO/OEPP, 2013. Diagnostics, PM 7/115 (1) Drosophila suzukii. Bull. OEPP/EPPO Bull., 43(3), 417-424.

Escudero-Colomar L.A., Vilajeliu M. \& Batllori L., 2008. Seasonality in the occurrence of the Mediterranean fruit 
fly [Ceratitis capitata (Wied.)] in the north-east of Spain. J. Appl. Entomol., 132(9-10), 714-721.

FAO/IAEA, 2003. Trapping guidelines for area-wide fruit fly programmes. Vienna: International Atomic Energy Agency.

Haniotakis G., 2005. Olive pest control: present status and prospects. IOBC/wprs Bull., 28(9), 1-9.

Hrnčić S., 2000. Izvještaj o pojavi, stanju, štetama i mjerama suzbijanja karantinskih, ekonomski štetnih $i$ ostalih biljnih bolesti $i$ štetočina u Crnoj Gori. Podgorica: Biotehnički Institut.

Hrnčić S., 2001. Izvještaj o pojavi, stanju, štetama i mjerama suzbijanja karantinskih, ekonomski štetnih $i$ ostalih biljnih bolesti $i$ štetočina u Crnoj Gori. Podgorica: Biotehnički Institut.

Hrnčić S., 2002. A survey of olive pest in Montenegro. Acta Hortic., 586, 819-821.

Hrnčić S., 2009. Official report to the Phytosanitary Directorate. Podgorica: University of Montenegro, Biotechnical Faculty.

Hrnčić S., 2014. Official report to the Phytosanitary Directorate. Podgorica: University of Montenegro, Biotechnical Faculty.

Hrnčić S., 2016. Official report to the Phytosanitary Directorate. Podgorica: University of Montenegro, Biotechnical Faculty.

Hrnčić S., 2017. Official report to the Directorate for Food Safety, Veterinary and Phytosanitary Affairs. Podgorica: University of Montenegro, Biotechnical Faculty.

Liquido N.J., Barr P.G. \& Cunningham R.T., 1998. MEDHOST: an encyclopedic bibliography of the host plants of the Mediterranean fruit fly, Ceratitis capitata (Wiedemann) (electronicdatabase/program). USDA, Agriculture Research Service. ARS - 144. In: Thompson F.C., ed. Fruit fly expert identification system and biosystematic information database. Diptera data dissemination disk (CD - Rom) (1998). Nashville, TN, USA: MEDHOST.

MacGowan I. \& Freidberg A., 2008. The Lonchaeidae (Diptera) of Israel, with descriptions of three new species. Isr. J. Entomol., 38, 61-92.

Mazomenos B., Pantazi-Mazomenou A. \& Stefanou D., 2002. Attract and kill of the olive fruit fly Bactrocera oleae in Greece as a part of an integrated control system. IOBC/wprs Bull., 25, 137-146.

Mifsud D. et al., 2012. On some arthropods associated with Ficus species (Moraceae) in the Maltese Islands. Bull. Entomol. Soc. Malta, 5, 5-34.

Mijušković M., 1959. Breskvina mušica, novi važan problem zaštite bilja kod nas. Naša Poljoprivreda, 5(1), 21-30.

Mijušković M. \& Mirčetić S., 1955. Ogledi suzbijanja maslinine mušice parationskim sredstvima na crnogorskom primorju. Zaštita bilja (Plant Protection), 31, 45-49.

Papadopoulos N.T. et al., 2001. Seasonal and annual occurrence of the mediterranean fruit fly (Diptera:
Tephritidae) in Northern Greece. Ann. Entomol. Soc. Am., 94(1), 41-51.

Perović T., Hrnčić S. \& Inđić D., 2009. Flight dynamics of olive fly Bactrocera oleae Gmel. (Diptera, Tephritidae) in the region of Bar. Pomologia Croatica, 15(3-4), 77-85.

Perović T. \& Hrnčić S., 2012. Carpomya vesuviana (Diptera, Tephritidae) a new pest in Montenegro. In: Proceedings of the Regional Symposium on the Management of Fruit Flies in Near East Countries, 6-8 November 2012, Hammamet, Tunisia. Book of Abstracts, 63.

Perović T. \& Hrnčić S., 2013. Population dynamics of pre-imaginal stages of olive fruit fly Bactrocera oleae Gmel. (Diptera, Tephritidae) in the Region of Bar (Montenegro). Pestic. Phytomed., 28(1), 23-29.

Radonjić S., 2006. The Mediterranean fruit fly, Ceratitis capitata (Wiedemann) (Diptera: Trypetidae), a new pest in Montenegro. IOBC/wprs Bull., 29(3), 217-224.

Radonjić S., 2008. The Mediterranean fruit fly, Ceratitis capitata (Wiedemann) (Diptera: Tephritidae) in the Montenegrin seacoast and its impact on agricultural production. Dissertation: Faculty of Agriculture, University of Belgrade, Zemun-Belgrade (Serbia).

Radonjić S., 2012. Official report to the Phytosanitary Directorate. Podgorica: University of Montenegro, Biotechnical Faculty.

Radonjić S., 2013. Official report to the Phytosanitary Directorate. Podgorica: University of Montenegro, Biotechnical Faculty.

Radonjić S., 2014. Official report to the Phytosanitary Directorate. Podgorica: University of Montenegro, Biotechnical Faculty.

Radonjić S., 2015. Official report to the Directorate for Food Safety, Veterinary and Phytosanitary Affairs. Podgorica: University of Montenegro, Biotechnical Faculty.

Radonjić S., 2016. Official report to the Directorate for Food Safety, Veterinary and Phytosanitary Affairs. Podgorica: University of Montenegro, Biotechnical Faculty.

Radonjić S., 2017. Official report to the Directorate for Food Safety, Veterinary and Phytosanitary Affairs. Podgorica: University of Montenegro, Biotechnical Faculty.

Radonjić S. \& Hrnčić S., 2009. The black fig fly Silba adipata McAlpine (Diptera, Lonchaeidae), a little known fig pest in Montenegro. Agroznanje (Agroknowledge), 10(4), 31-41.

Radonjić S. \& Hrnčić S., 2011. The Mediterranean fruit fly Ceratitis capitata Wiedem.: spreading on new locations in Montenegro and detection on new host plant. Biljni lekar (Plant Doctor), 39(5), 511-517.

Radonjić S., Čizmović M. \& Pereira R., 2013. Population dynamics of the Mediterranean fruit fly in Montenegro. Int. J. Insect Sci., 5, 35-40.

Radonjić S. \& Hrnčić S., 2015. First record of spotted wing drosophila Drosophila suzukii (Diptera: Drosophilidae) in Montenegro. Pestic. Phytomed., 30(1), 35-40. 
Remsen J. \& O'Grady P., 2002. Phylogeny of Drosophilinae (Diptera: Drosophilidae), with comments on combined analysis and character support. Mol. Phylogenet. Evol., 24(2), 249-264.

Vadivelu K., 2014. Biology and management of ber fruit fly Carpomyia vesuviana Costa (Diptera, Tephritidae): a review. Afr. J. Agric. Res., 9(16), 1310-1317.

UNDP, 2018. United Nations Development Programme, Montenegro, https://www.adaptation-undp.org/explore/ southern-europe/montenegro, (05/04/2018).

Velimirović V., 1988. Izvještaj o pojavi, stanju, štetama $i$ mjerama suzbijanja karantinskih, ekonomski štetnih $i$ ostalih biljnih bolesti $i$ štetočina u Crnoj Gori. Titograd: Poljoprivredni Institut.

Velimirović V., 1989. Izvještaj o pojavi, stanju, štetama $i$ mjerama suzbijanja karantinskih, ekonomski štetnih $i$ ostalih biljnih bolesti i štetočina u Crnoj Gori. Titograd: Poljoprivredni Institut.
Velimirović V., 1990. Izvještaj o pojavi, stanju, štetama $i$ mjerama suzbijanja karantinskih, ekonomski štetnih $i$ ostalih biljnih bolesti i štetočina u Crnoj Gori. Titograd: Poljoprivredni Institut.

Walsh D.B. et al., 2011. Drosophila suzukii (Diptera: Drosophilidae): invasive pest of ripening soft fruit expanding its geographic range and damage potential. J. Integr. Pest Manage., 2(1), 1-7.

White I.M. \& Elson-Harris M.M., 1992. Fruit flies of economic significance: their identification and bionomics. Wallingford, Oxon, UK: CAB International.

Yeates D. et al., 2007. Phylogeny and systematics of Diptera: two decades of progress and prospects. Zootaxa, $\mathbf{1 6 6 8}$, 565-590.

ZHMS, 2018. Zavod za hidrometeorologiju i seizmologiju, https://www.meteo.co.me, (05/04/2018).

(54 ref.) 